\title{
TUTUP TEMPAT SAMPAH OTOMATIS MENGGUNAKAN SENSOR ULTRASONIK BERBASIS MIKROKONTROLER ARDUINO UNO
}

\author{
Rahmad Kurniawan ${ }^{1}$, Nur Rubiati ${ }^{2}$, Shella Yuliana $\mathbf{Z R}^{3}$ \\ ${ }^{1,2,3}$ Sekolah Tinggi Manajemen Informatika dan Komputer (STMIK) Dumai \\ JL. Utama Karya Bukit Batrem Kec. Dumai Timur Kode pos 28811 \\ e-mail : rahmad0412@gmail..com ${ }^{1}$, nurrubiati0412@gmail.com² \\ shellayuliana.zr@gmail.com ${ }^{3}$
}

\begin{abstract}
ABSTRAK
Dalam meningkatkan kesadaran akan kepedulian terhadap kebersihan lingkungan, memerlukan cara yang unik agar tiap-tiap individu tertarik, sehingga tak segan untuk membuang sampah pada tempatnya. Tempat sampah pada umumnya membuka dan menutupnya secara manual. Hal ini menyulitkan seseorang untuk membuang sampah ataupun membersihkan sampah yang sudah penuh. Memberikan solusi dengan membuat tempat sampah otomatis berbasis Arduino Uno, menggunakan sensor HC-SR04, motor servo, rangkaian adaptor, dan LED. Tempat sampah ini menggunakan sensor HC-SR04 berbasis Arduino board sebagai pendeteksi jarak, sedangkan motor servo digunakan sebagai penggerak buka dan tutup tempat sampah, dan LED sebagai notifikasi bahwa tempat sampah dalam kondisi aktif. LED biru di sisi depan tempat sampah sebagai indikator pemberitahuan bahwa temat sampah dalam kondisi aktif, dan LED hijau sebagai indikator pemberitahuan bahwa temat sampah sedang membaca benda di depan sensor sehingga menggerakkan Motor servo untuk terbuka.
\end{abstract}

Kata Kunci : Arduino Uno, Arduino IDE, Tempat sampah otomatis, Sensor jarak HC-SR04, Servo.

\section{ABSTRACT}

In raising awareness of caring for environmental cleanliness, it requires a unique way so that each individual is interested, so that he is not reluctant to dispose of garbage in its place. Trash can in general open and close it manually. This makes it difficult for someone to dispose of trash or clean up trash that is already full. Providing solutions by making Arduino Uno based automatic bins, using HC-SR04 sensors, servo motors, adapter circuits, and LEDs. This trash can uses the HC-SRO4 sensor based on Arduino board as distance detection, while the servo motor is used as a drive to open and close the trash, and the LED as a notification that the trash can is active. Blue LED on the front side of the trash can as a notification indicator that the trash can is active, and a green LED as a notification indicator that the trash can is reading objects in front of the sensor so that it moves the servo motor to open.

Keywords: Arduino Uno, Arduino IDE, Automatic Trash, HC-SR04 proximity sensor, Servo.

\section{PENDAHULUAN}

Sampah merupakan material sisa yang tidak diinginkan setelah berakhirnya suatu proses.
Sampah didefinisikan oleh manusia menurut derajat keterpakaiannya, dalam proses-proses alam sebenarnya tidak ada konsep sampah, yang 
IN F O R M A I I A

Jurnal Informatika, Manajemen dan Komputer, Vol. 13 No. 2, Desember 2021

eISSN : 2580-3042

pISSN : 1979-0694

ada hanya produk-produk yang dihasilkan setelah dan selama proses alam tersebut berlangsung. Dalam kehidupan manusia, sebagian besar akan menghasilkan sampah. Sampah tersebut akan menumpuk di tempat pembuangan sampah. Apabila tumpukan semakin meningkat tersebut tidak di imbangi dengan pengelolaan yang tidak baik maka akan muncul permasalahan terutama bagi penduduk atau yang tinggal disekitar tempat sampah tersebut. Beberapa jenis sampah harus dibuang sesegera mungkin dan sejauh mungkin karena dapat membusuk sehingga mengeluarkan bau yang tidak sedap.

Masalah tersebut diperparah oleh kurang kesadaran masyarakat tentang pengetahuan bahaya sampah. Sehingga banyak masyarakat yang membuang sampah sembarangan tanpa memikir dampak akibatnya. Salah satu penyebab kenapa masyarakat malas untuk membuang sampah pada tempatnya karena kondisi tempat sampah yang kotor, bau yang menyengat dan penuh kuman. Pengguna harus bersentuhan langsung dengan tempat sampah untuk membuang sampah. apalagi memegang dan membuka tutup tempat sampah yang mungkin penuh dengan air ludah atau entah cairan apa.

Maka, dibuatlah tempat sampah otomatis dengan menggunakan sensor ultrasonik berbasis Mikrokontroler Arduino Uno. Sensor jarak ultrasonik berfungsi untuk mendeteksi adanya benda dalam jarak tertentu. Sehingga tempat sampah bisa terbuka dengan otomtis tanpa tersentuh oleh masyarakat yang ingin membuang sampah.

Dari latar belakang di atas penulis berinisiatif membuat tugas akhir yang berjudul "Tutup Tempat Sampah Otomatis menggunakan sensor Ultrasonik Berbasis Mikrokontroler Arduino Uno" yaitu sebuah tempat sampah pintar yang pengoprasiannya dilakukan secara otomatis.

\section{a. Sistem}

Menurut Kristanto (2008:1), Suatu sistem adalah jaringan kerja dari prosedur-prosedur yang saling berhubungan, berkumpul bersama-sama untuk melakukan suatu kegiatan atau menyelesaikan suatu sasaran tertentu. Suatu sistem yang baik harus mempunyai tujuan dan sasaran yang tepat karena hal ini akan sangat menentukan dalam mendefenisikan masukan yang dibutuhkan sistem dan juga keluaran yang dihasilkan.(Ridarmin \& Zulizha, 2018)

\section{b. Defenisi Informasi}

Informasi adalah data yang telah diklasifikasi atau diinterpretasi untuk digunakan dalam proses pengambilan keputusan. Sistem pengolahan informasi mengolah data menjadi informasi atau tepatnya mengolah data dari bentuk tak berguna menjadi berguna bagi penerimanya. (Sutabri, 2012:29).

Informasi adalah data yang diolah menjadi bentuk yang lebih berguna dan lebih berarti bagi yang menerimanya. (Hartono, 2005: 8).

\section{c. Defenisi Data}

Data adalah sebagai bahan keterangan tentang kejadian nyata atau fakta-fakta yang dirumuskan dalam sekelompok lambang tertentu yang tidak acak yang menunjukan jumlah, tindakan, atau hal. Data dapat perupa catatan-catatan dalam kertas, buku, atau tersimpan sebagai file dalam basis data. (Sutana, 2011:14)

Data merupakan bentuk yang masih mentah yang belum dapat berceritra banyak, sehingga perlu diolah lebih lanjut. Data diolah melalui suatu model untuk dihasilkan informasi, data merupakan bentuk jamak dari bentuk tunggal datum atau data item. Data adalah kenyataan yang menggambarkan suatu kejadian - kejadian dan kesatuan nyata. (Hartono, 2005: 8)

\section{d. Pengertian Flowcart}

Flowchart adalah suatu metode pemecahan masalah yang digambarkan dengan mempresentasikan symbol-simbol tertentu yang mudah dimengerti, mudah digunakan dan standar. Tujuan utama dari pemakaian flowchart adalah untuk menggambarkan suatu tahapan penyelesaian masalah secara sederhana, terurai, rapi, dan jelas dengan menggunakan simbol simbol yang standar. (Yuswanto, 2009: 16).

Bagan alir (flowcart) adalah bagan yang menunjukkan alir dalam program atau prosedur sistem secara logika, bagan alir digunakan terutama untuk alat bantu komunikasi dan untuk dokumentasi. (Hartono, 2005:795).

\section{e. Tempat Sampah}

Tempat sampah adalah tempat untuk menampung sampah secara sementara, yang biasanya terbuat dari logam atau plastik. Di dalam ruangan tempat sampah umumnya disimpan di dapur untuk membuang sisa keperluan dapur seperti kulit buah atau botol. Ada juga tempat sampah khusus kertas yang digunakan di kantor. Beberapa tempat sampah memiliki penutup pada bagian atasnya untuk 
IN F ORM T I K

Jurnal Informatika, Manajemen dan Komputer, Vol. 13 No. 2, Desember 2021

eISSN : 2580-3042

pISSN : 1979-0694

menghindari keluarnya bau yang dikeluarkan sampah. Kebanyakan harus dibuka secara manual, namun saat ini sudah banyak yang menggunakan pedal untuk memudahkan membuka tutup tempat sampah.Tempat sampah dalam ruangan umumnya dilapisi kantong untuk memudahkan pembuangan sehingga tidak perlu memindahkan tempat sampah ketika sudah penuh, cukup dengan membawa kantong yang melapisi tempat sampah lalu menggantinya dengan yang baru. Hal ini memudahkan pembuangan sampah.

\section{f. Mikrokontroler}

Mikrokontroler adalah sebuah sistem komputer fungsional dalam sebuah chip, didalam terkandung sebuah inti prosesor, memori, dan perlengkapan input-output, salah satu dari bagian dasar dari suatu sistem komputer. Seperti umumnya komputer mikrokntroler adalah alat yang mengerjakan instruksi-instruksi yang diberikan kepadanya. Artinya bagian terpentin dan utama dari suatu sistem terkomputerisasi adalah program itu sendiri yang disebut oleh seorang progrwmmer. Program ini menginstruksikan komputer untuk melakukan jalinan yang panjang dari aksi-aksi sederhana untuk melakukan tugas yang lebih kompleks yang diinginkan oleh programmer. (Syahwil, 2013:53)

Arduino UNO adalah sebuah board mikrokontroler yang didasarkan pada ATmega328. Arduino UNO mempunyai 14 pin digital input/output (6 di antaranya dapat digunakan sebagai output PWM), 6 input analog, sebuah osilator Kristal $16 \mathrm{MHz}$, sebuah koneksi USB, sebuah power jack, sebuah ICSP header, dan sebuat tombol reset.(Arie Linarta, 2018:2)

Arduino adalah sebuah platform elektronika yang bersifat open source serta mudah digunakan. (wicaksono et all, 2017:1)

\section{g. Sensor Ultrasonik}

Sensor ultrasonik atau dinamakan sensor sonar adalah sensor yang menggunkan suara ultrasonik untuk mendeteksi objek yang ada dihadapannya dan dapat digunakan menghitung jarak terhadap objek tertentu. (Abdul Kadir, 2018:233)

Sensor ultrasonik adalah sensor yang bekerja berdasarkan prinsip pantulan gelombang suara, di mana sensor menghasilkan gelombang suara yang kemudian menangkapnya kembali dengan perbedaan waktu sebagai dasar pengindraannya. Perbedaan waktu antara gelombang suara yang

dipancarkan dan yang di terima kembali adalah berbanding lurus dengan jarak atau tinggi objek yang memantulkannya. Sensor ini dapat mengukur $2 \mathrm{~cm}$ sampai $300 \mathrm{~cm}$. (Elisawati, 2017)

\section{h. Software Arduino IDE}

IDE (Integrated Development Environment) adalah sebuah software untuk menulis program, mengompilasi menjadi kode biner dan mengupload ke dalam memory mikrokontroler. (Syahwill, 2013: 9)

Ketika kita membuka program Arduino IDE (Integrated Development Enviroment). Jika kita menggunakan Windows atau Linux, akan terlihat perbedaan, tetapi pada dasarnya IDE (Integrated Development Enviroment) akan sama tidak perduli Operasi Sistemnya apa yang digunakan. Untuk memulai Serial Monitor, tekan tombol. Serial Monitor dan untuk menghentikan tekan tombol Stop. Pada Linux, Arduino akan me-reset sendiri ketika meng-klik tombol Serial Monitor. Untuk mengoprasikan atau menggabungkan Arduino pada PC (Personal Computer), kita dapat menggunakan program-program seperti Processing, Flash, MaxMSP, Visual Basic, dan lain - lain. (Gunardi, 2012: 275)

\section{i. Motor servo}

Menurut Syahrul (2014:370) Motor servo merupakan salah satu jenis aktuator elektromekanis yang tidak bergerak secara kontinyu, tetapi bergerak pada posisi tertentu dan kemudian berhenti disana. Walau demikian, untuk beberapa keperluan tertentu, motor servo dapat dimodifikasi agar bergerak kontinyu. Motor servo juga menggunakan mekanisme umpan balik dimana pada pergerakannya dapat merasakan kesalahan dalam posisinya kemudian mengoreksinya. (Reza et all (2017).

Motor servo adalah sebuah perangkat atau aktuator putar (motor) yang dirancang dengan sistem kontrol umpan balik loop tertutup (servo), sehingga dapat di set-up atau di atur untuk menentukan dan memastikan posisi sudut dari poros output motor. Motor servo merupakan perangkat yang terdiri dari motor DC, serangkaian gear, rangkaian kontrol dan potensiometer. Serangkaian gear yang melekat pada poros motor DC akan memperlambat putaran poros dan meningkatkan torsi motor servo, sedangkan potensiometer dengan perubahan resistansinya saat motor berputar berfungsi sebagai penentu batas posisi putaran poros motor servo. (Sukarjadi et all, 2017). 
IN F O R M A I I A

Jurnal Informatika, Manajemen dan Komputer, Vol. 13 No. 2, Desember 2021

eISSN : 2580-3042

pISSN : 1979-0694

\section{j. $\quad L E D$}

LED (Light Emitting Diode)adalah komponen yang dapat memancarkan cahaya jika dialiri arus listrik. Komponen ini umumnya mempunyai dua kaki. Salah satu kaki bernama anode dan kaki lainnya bernama katode. LED hanya menyala jika tegangan positif diberikan kepada anode dan tegangan negatif kepada katode. Kalau polaritas tegangan terbalik LED tidak akan menyala. (Abdul Kadir, 2018:19)

LED adalah semikonduktor yang dapat mengubah energi listrik lebih banyak menjadi cahaya, merupakan perangkat keras dan padat (solid-state component) sehingga lebih unggul dalam ketahanan (durability). (Suhardi, 2014:116)

\section{METODOLOGI PENELITIAN}

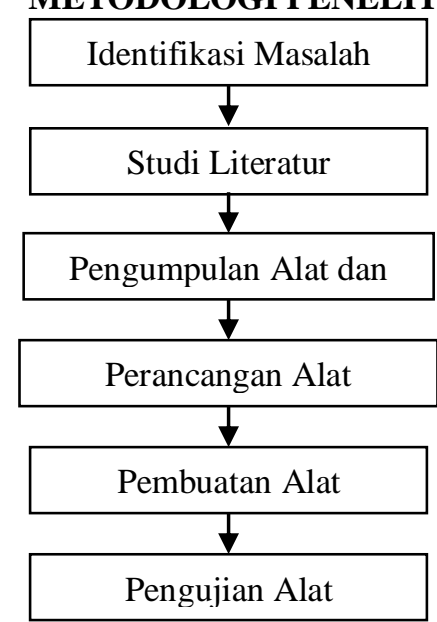

Gambar 1. Kerangka Kerja.

Berdasarkan penjelasan diatas, dapat dijabarkan urutan-urutan langkah kerja sebagai berikut:

1. Identifikasi masalah.

Menurut Prof. Dr. Jogiyanto HM. MBA, Akt. Mengidentifikasi (mengenal) masalah merupakan langkah pertama yang dilakukan dalam tahap analisis sistem.

2. Studi Literatur

Untuk mengetahui solusi, cara atau metode yang aka digunakan dalam pemecahan masalah yang ada pada studi literatur meliputi studi pustaka yang bersumber dari buku, jurnal, dan juga internet untuk mengetahui bagaimana cara membangun sebuah alat tempat sampah otomatis

3. Pengumpulan alat dan bahan

Dalam pembuatan tempat sampah otomatis ini menggunakan mikrokontroler arduino uno, sensor ultrasonik, dan beberara komponen pendukung lainnya.

4. Perancangan alat

membuat perancangan alat sementara yang berfokus penyajian (contoh membuat input dan format output).

5. Pembuatan Alat.

Merupakan tahapan merangkai atau merancang alat dan bahan yang sudah disiapkan sesuai dengan logika yang telah dirancang untuk membuat alat tempat sampah otomatis.

6. Pengujian Alat

Setelah selesai dengan pembuatan alat, maka perlu dilakukan pengujian terhadap alat yang telah dibuat apakah berjalan sesuai dengan yang telah direncanakan

\section{HASIL DAN PEMBAHASAN}

a. Perangkat lunak yang digunakan

\section{1) Sistem Operasi}

Sistem operasi yang digunakan dalam penelitian ini adalah Windows

\section{2) ArduinoIDE}

ArduinoIDE merupakan perangkat lunak yang berasal dari Arduino sendiri yang digunakan untuk pemrograman pada arduino.

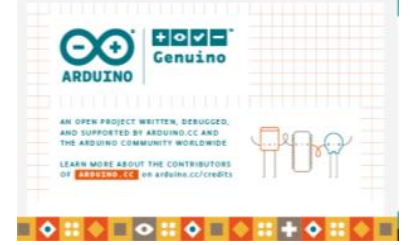

Gambar 2. Tampilan awal Arduino Uno

b. Perangkat Keras yag digunakan

Komponen perangkat keras yang digunakan adalah:

a. Perangkat komputer

b. Modul sensor ultrasonik

c. Arduino Uno dan Kabel USB

d. Servo dan LED

e. Tempat sampah

c. Rangkaian Komponen

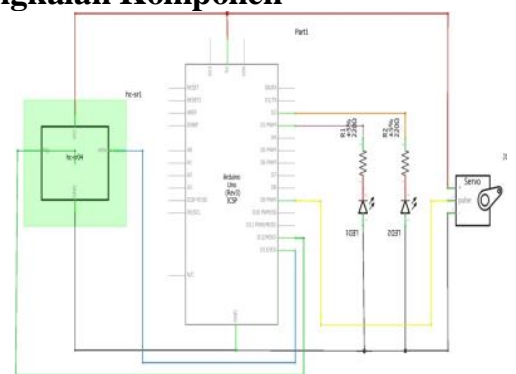

Gambar 3. Rangkaian Skematik seluruh komponen 
IN F O R M A I I A

Jurnal Informatika, Manajemen dan Komputer, Vol. 13 No. 2, Desember 2021

eISSN : 2580-3042

pISSN : 1979-0694

Cara kerja Pembuka dan penutup bak sampah otomatis ini berdasarkan inputan dari sensor jarak ultrasonik. Apabila sensor jarak ultrasonik menangkap suatu aktivitas di dekat bak sampah dalam hal ini tangan seseorang dengan jarak $20 \mathrm{~cm}$ maka motor servo akan bergerak, serta lampu indikator warna hijau akan hidup, dan membuka tutup tempat sampah, selama sensor membaca adanya benda di dekatnya, tutup tempat sampah akan terus terbuka, dan menutup denga sendirinya jika sensor sudah tidak membaca adanya benda atau aktifitas lainnya.

\section{1) Perancangan Sensor HC-SR04 dengan} Mikrokontroler Arduino Uno.

Bagian ini berfungsi sebagai alat input. Sensor HC-SR04 dimanfaatkan untuk mendeteksi adanya jarak mendekat.

Pin 5V pada Arduino di hubungkan ke VCC sensor ultrasonik.

Pin 12 pada Arduino dihubungkan ke Pin Trig pada Sensor Ultrasonik.

Pin 13 pada Arduino dihubungkan ke Pin Echo pada Sensor Ultrasonik.

Pin GND pada Arduino dihubungkan ke Pin GND pada Sensor Ultrasonik

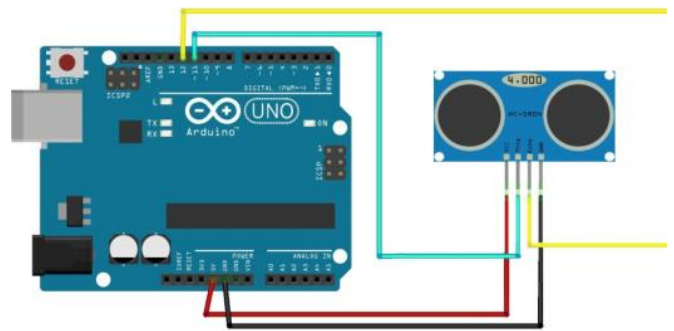

Gambar 4 Perancangan Arduino-Sensor

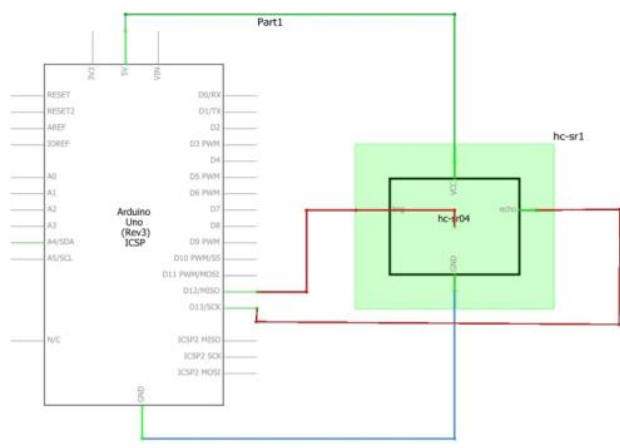

Gambar 5. Rangkaian Skematik ArduinoSensor

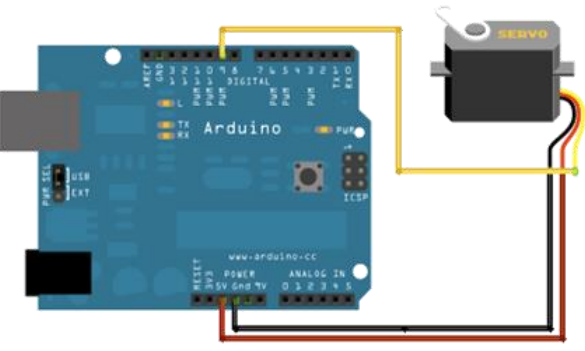

Gambar 6. Perancangan Arduino-Servo

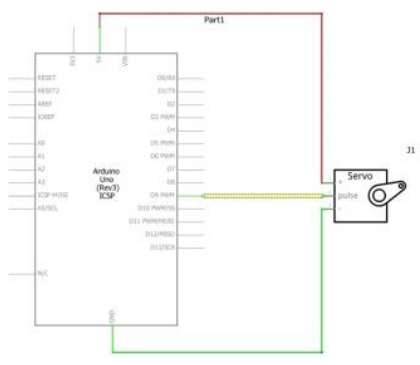

Gambar 7. Rangkaian Skematik ArduinoServo

\section{3) Perancangan LED dengan}

Mikrokontroler Arduino Uno

LED (Light Emitting Diode) sebagai notifikasi berupa pancaran cahaya monokromatik ketika diberikan tegangan maju. Pin 2 Arduino dihubungkan ke LED Biru

Pin 3 Arduino dihubungkan ke LED Hijau

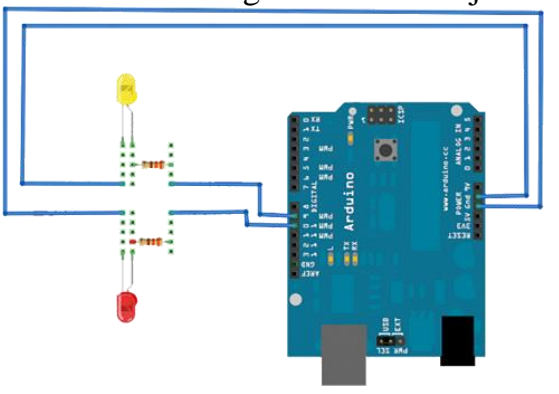

Gambar 8. Perancangan Arduino-LED 
I N F O R M A T I K A

Jurnal Informatika, Manajemen dan Komputer, Vol. 13 No. 2, Desember 2021

elSSN : 2580-3042

pISSN : 1979-0694

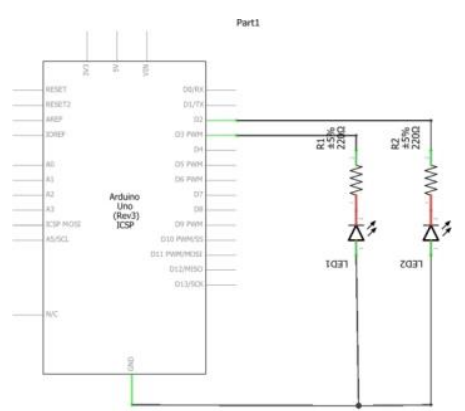

Gambar 9. Rangkaian Skematik ArduinoLED

\section{d. Pemodelan Logika dan Algoritma.}

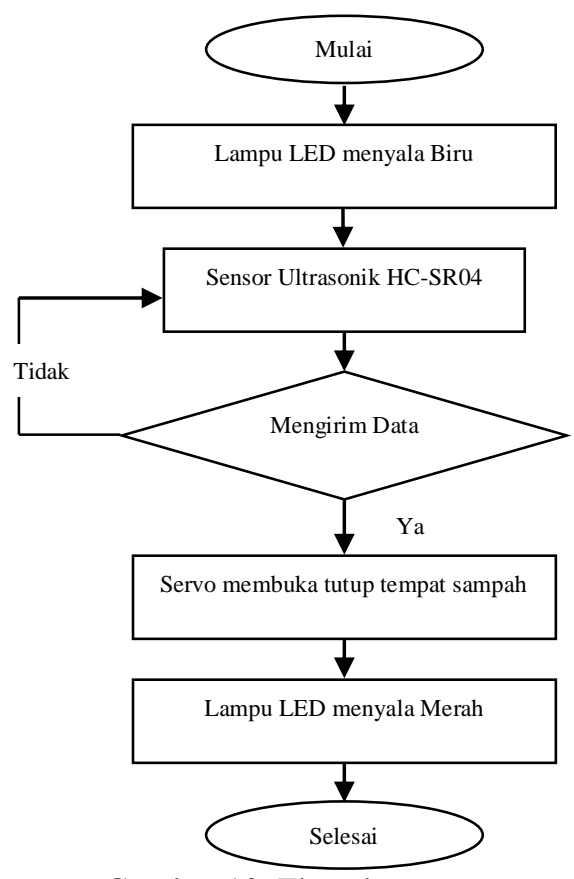

Gambar 10. Flowchart

\section{e. Input koding ke arduino}

Langkah berikutnya memasukkan koding ke Arduino, hubungkan kabel USB ke Port USB Arduino, dan setelah itu hubungkan ujung kabel Port USB ke laptop yang sudah terinstal IDE Arduino dapat dilihat pada gambar dibawah ini:

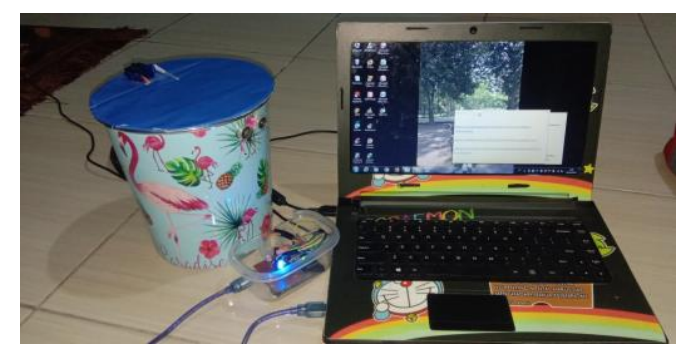

Gambar 11. Kabel Port usb arduino terhubung ke laptop

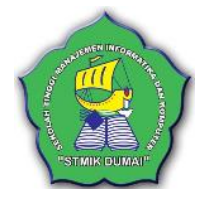

\section{f. Komponen yang dirangkai}

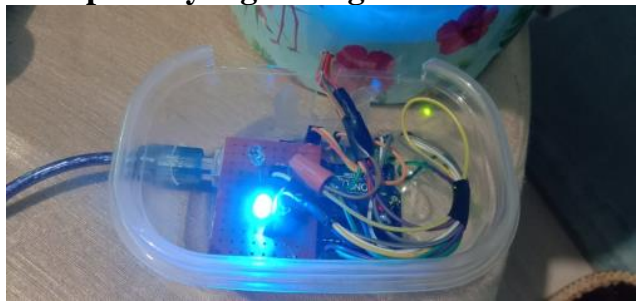

Gambar 12. Susunan rangkaian pada alat

Bagian utama dari perangkat ini terbuat dari plastik seperti tempat sampah umum. Dapat dilihat bahwa alat memiliki 1 sensor ultrasonik, motor servo, LED, dan Port powersuplay yang sudah langsung terdapat di arduino yang terletak di dalam kotak sebagai sumber listrik. Sensor ultrasonik yang terletak di luar berfungsi mendeteksi objek sebagai masukan sinyal ke mikrokontroler. Jika sensor membaca adanya benda dalam jangkauan $25 \mathrm{~cm}$ di depan, maka sensor akan mengirimkan data kepada Arduino untuk di proses.

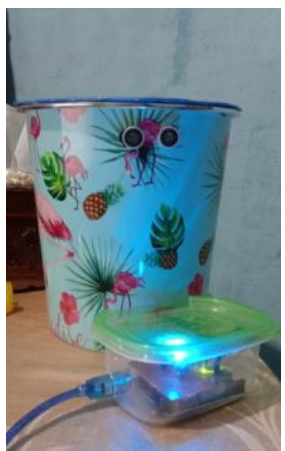

Gambar 13. Tempat sampah dalam keadaan aktif

LED biru di sisi depan tempat sampah sebagai indikator pemberitahuan bahwa temat sampah dalam kondisi aktif, dan LED hijau sebagai indikator pemberitahuan bahwa temat sampah sedang membaca benda di depan sensor sehingga menggerakkan Motor servo untuk terbuka.
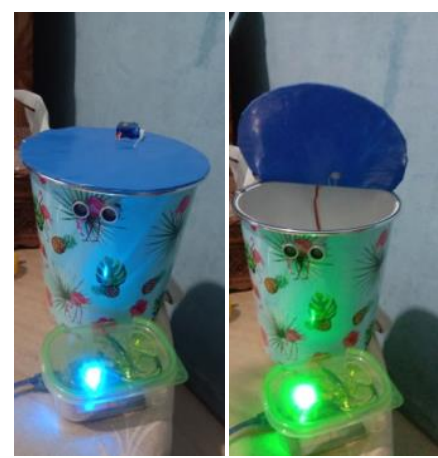

Gambar 14. Tempat sampah dalam kondisi tertutup dan terbuka 
I N F O R M A T I K A

Jurnal Informatika, Manajemen dan Komputer, Vol. 13 No. 2, Desember 2021

eISSN : 2580-3042

pISSN : 1979-0694

\section{KESIMPULAN}

Dengan melakukan perancangan dan pengujian sistem kerja tempat sampah otmatis ini, maka dapat ditarik sebuah kesimpulan yaitu:

a. Sistem tempat sampah otomatis menggunakan sensor ultrasonik

b. Sensor mendeteksi benda sesuai dengan jarak yang ditentukan, dan membuat tutup tempat sampah akan terbuka, sehingga sampah bisa dimasukkan.

c. LED biru akan menyala jika Tempat Sampah dalam keadaan aktif, sedangkan LED hijau akan menyala jika sensor membaca benda dalam jarak ditentukan.

\section{REFERENSI}

Diding Suhardi. (2014). Prototipe Controller Lampu Penerangan Led (Light Emitting Diode) Independent Bertenaga Surya, Gamma Journal, V.10, No.1, 116-122

Elisawati. (2017). Sistem Deteksi Objek Menggunakan Sensor Ultrasonik Berbasis Fuzzy, Jurnal Informatika, Manajemen Dan Komputer V.9, No1.

Gunardi, Y. (2012). Perancangan San Pembuatan Penetas Telur Berbasis Arduino Dumilanove. Prosiding SNPPTI.

Hartono, Jogiyanto. 2005. Analisis Dan Desain Sistem Informasi Pendekatan Terstruktur Teori Dan Praktek Aplikasi Bisnis. Ed. III, Andi, Yogyakarta.

Kadir, Abdul., Triwahyuni, Terra Ch. 2013. Pengantar Teknologi Informasi. Edisi II, Andi, Yogyakarta.

Reza Lutfi Ismai, Jatmiko Endro Suseno Dan Suryono Suryono. (2017). Rancang Bangun Sistem Pengaman Kebocoran Gas LPG (Liquefied
Petroleum Gas) Menggunakan Mikrokontroler,Youngster Physics Journal, V.6, No.4, 36-92.

Ridarmin, Zulizha. (2018). Prototype Penyiram Tanaman Hias Dengan Soil Moiseture Sensor Berbasis Arduino, Jurnal Informatika, V.10, No1.

Sukarjadi, Deby Tobagus, Arifiyanto Dan Moch.Hatta. (2017). Perancangan Dan Pembuatan Smart Trash Bin Berbasis Arduino Uno Di Universitas Maarif Hasyim Latif, Engineering And Sains Journal, V.1, No.2, 101-110.

Sutanta, Edhy. 2011. Basis Data Dalam Tinjauan Konseptual. Ed.I, Andi, Yogyakarta.

Syahwill, Mohammad. 2013. Panduan Mudah Simulasi Dan Praktek Mikrokontroler Arduino. Ed.I, Andi, Yogyakarta

Sutabri, Tata. 2012. Analisis Sistem Informasi. Ed. 1. Andi, Yogyakarta.

Wicaksono, Mochamad Fajar., Hidayat. 2017. Mudah Belajar Mikrokontroler Arduino. Pertama. Informatika Bandung.

Yuswanto. 2009. Algoritma \& Pemrograman Dengan Visual Basic .NET 2005. Edisi Pertama, Cerdas Pustaka Publisher, Jakarta. 